\title{
Evaluation of the compressive strength of commercial sandcrete blocks produced in two metropolises of Delta State, Nigeria
}

\author{
Akpokodje, O. I. ${ }^{1}$, Agbi, G. G. ${ }^{2}$, Uguru, $\mathrm{H}^{3 *}$ and Nyorere, $\mathrm{O} .^{3}$ \\ ${ }^{1}$ Department of Civil Engineering Technology, Delta State Polytechnic, Ozoro, Nigeria. \\ ${ }^{2}$ Department of Civil Engineering, Delta State University, Oleh Campus, Nigeria. \\ ${ }^{3}$ Department of Agricultural and Bio-Environmental Engineering Technology, Delta State Polytechnic, Ozoro, Nigeria. \\ ${ }^{*}$ Corresponding author. Email: erobo2011@gmail.com
}

Copyright $@ 2021$ Akpokodje et al. This article remains permanently open access under the terms of the Creative Commons Attribution License 4.0, which permits unrestricted use, distribution, and reproduction in any medium, provided the original work is properly cited.

Received 8th April, 2021; Accepted 29th April, 2021

\begin{abstract}
The mechanical properties of sandcrete block greatly influenced the durability of structures built from it. This study was carried out to assess the compressive strength of sandcrete blocks produced in two major developmental and rapidly urbanizing zones of Delta State, Nigeria. 150 and $225 \mathrm{~mm}$ sandcrete blocks were sampled from 18 blocks moulding factories in Ndokwa East and Ughelli North Local Government Areas of Delta State, Nigeria. Five sandcrete block was sampled from each block moulding factory, at the rate of 9 factories per Local Government Area. The compressive strength of the sampled blocks was determined in accordance with the ASTM International standards. The results of compressive strength test showed that the compressive strengths of the blocks, regardless of the block size ranged from 0.61 to 16.19 $\mathrm{MPa}$. Analysis of the results revealed that apart from the customized blocks, the compressive strengths of all the other blocks fell below the Nigerian Industrial Standard (NIS) recommendations of $2.5 \mathrm{MPa}$ for non-load bearing walls. The general poor quality of the sandcrete blocks is attributed particularly to the poor mix ratios adopted by the block producers which fell short of NIS recommendations. Thus, this study recommended that standard regulatory agencies should closely monitor all the block making factories in the state, to ensure that sandcrete blocks produced or brought into the state met NIS recommendations.
\end{abstract}

Keywords: Block factory, compressive strength, Delta State, mix ratio, sandcrete blocks.

\section{INTRODUCTION}

There are several types of materials used for the construction of walls in buildings and other related structures. Some common building materials employed include: precast concrete, sandcrete blocks, wood, metal sheets, gabion, bricks, insulated vinyl, structural insulated panels, etc. The choice of any construction material by a structural engineer (for a particular building or structure) is dependent on the structural integrity required, cost, ease of maintenance, durability, availability of the materials, etc. Citing Food Agricultural Organization (FAO), a good structural material for a wall must provide strength and stability, water and fire resistance, and thermal sound insulation to the structure. Due to the climatic conditions in the Tropics, structural walls are designed to allow the movement of heat and air within and throughout the structure. This is why hollow sandcrete blocks are commonly used in the construction of residential structures as well as farm buildings (FAO, 1988).

Sandcrete blocks are produced from a mixture of cement and fine aggregate (sand), manually compacted or mechanically compacted by a block moulding machine. The cement and fine aggregate are mixed together in volumetric ratios (cement: sand) of 1:6, 1:7, 1:8, 1:9, etc. Sandcrete blocks have become an important building material for construction works, mostly in African countries; especially with regards to the development and rapid 
urbanization of its towns and city centres, following commercial growth and industrialization. Baiden and Tuuli (2004) reported that about $90 \%$ of structural infrastructures in Nigeria are constructed with sandcrete blocks. Sandcrete blocks are widely used in the construction of load bearing and non-load bearing building walls (Agbi et al., 2020). Food Agricultural Organization states that a load-bearing walls of an unframed building supports directly all the floors and roof loads in addition to its own weight, and also it resists lateral pressures from the prevailing winds. While the non-load-bearing walls do not supports floor or roof loads (FAO, 1988). There are two major types of sandcrete blocks; the solid and hollow forms. According to Odeyemi et al. (2018), solid sandcrete blocks have no openings in their mass; while hollow sandcrete blocks have major openings within the block mass running from top to bottom, which occupies about $35 \%$ of the total volume of the block.

The mechanical properties of sandcrete blocks are greatly influenced by: the type of cement used, the nature of the fine aggregate, the production method adopted, the curing method and the curing period, as well as the size and type (solid or hollow) of the blocks (Akpokodje and Uguru, 2019). In Nigeria, sandcrete blocks are commercially produced in makeshift structures both in the rural and urban areas and without adequate attention given to the quality of the sandcrete blocks produced. The block producers, apart from when the consumers place special orders, do not follow any internationally recognized standard for sandcrete block production. However, the customized blocks (special order blocks) which are more likely produced based on recommendations approved by the Nigeria Industrial Standard (NIS), are always more expensive than the ordinary ((uncustomized) produced blocks. Negligence on the part of the sandcrete blocks producers, has led to a general poor quality of the commercially produced blocks in Nigeria. The Nigeria Industrial Standard recommends a minimum compressive strength of $2.5 \mathrm{Nmm}^{-2}$ for sandcrete blocks to be used for the construction of non-load bearing wall, and $3.45 \mathrm{Nmm}^{-2}$ for sandcrete blocks to be used in the construction of load bearing walls (NIS, 2000).

Research has shown that majority of the sandcrete blocks produced in Nigeria were unable to meet NIS recommendations; therefore, making them unsafe for building constructions (Agbi et al. 2020). Anosike and Oyebade (2011) observed that the compressive strength of the sandcrete blocks commercially produced in Ota, Ogun State, Nigeria, and in the Nigeria Federal Capital Territory, Abuja, fell below the NIS specification. According to Ambrose et al. (2019), the compressive strength of blocks sampled from 12 block manufacturing industries in Akwa Ibom State, southern Nigeria ranged between 0.19 and $1.32 \mathrm{Nmm}^{-2}$. A similar similar study in Akure, Ondo State, Nigeria, showed that the highest compressive strength of sandcrete blocks randomly sampled within the city was $1.35 \mathrm{Nmm}^{-2}$ (Aiyewalehinmi and Tanimola, 2013).
Likewise, Ewa and Ukpata (2013) reported that the compressive strength of sandcrete blocks sampled from 10 block industries within Calabar metropolis, Southern Nigeria, ranged between 0.23 and $0.58 \mathrm{Nmm}^{-2}$. The compressive strength of sandcrete blocks sampled from block manufacturing industries within Kano metropolis, Northern Nigeria, ranged between 0.25 and $0.92 \mathrm{Nmm}^{-2}$, portraying that all the sandcrete blocks were substandard compared to NIS requirement (Mohammed and Anwar, 2014). According Akeem and Umar (2013) and Agbi et al. (2020), poor quality sandcrete blocks is one of the major factors that can lead to structural failures, which is recently on the increase in Nigeria. Omoregie and Alutu (2006) stated that substandard sandcrete blocks can collapse under its self-weight; therefore, leading to structural failures. According to Ayedun et al. (2010), substandard sandcrete blocks is one of the factors contributing to the continuous building collapses witnessed in Lagos state. Many Nigerians often buy substandard blocks at lower prices rather than high quality blocks sold at higher price rates.

According to Nigeria Building Codes, sandcrete blocks to be used for the construction of load bearing walls must conform to NIS recommendations. Literature reviews on the subject matter have shown no recorded data on the compressive strength of sandcrete blocks commercially produced in Ndokwa East and Ughelli North Local Government Areas of Delta State, Nigeria. Both metropolises are rapidly urbanizing and densely populated. Therefore, the objective of this study is to evaluate the quality (compressive strength) of commercially produced sandcrete blocks within Ndokwa East and Ughelli North metropolises of Delta State, Nigeria. Results of this study will be useful to relevant authorities in monitoring the quality of sandcrete blocks produced within Delta State and its environs.

\section{MATERIALS AND METHODS}

\section{Study areas description}

This study was carried out within Ndokwa East and Ughelli north Local Government Areas of Delta State. Kwale is located in Ndokwa East Local Government Area of Delta State with a population of about 142,200 people and land mass of $1,614 \mathrm{~km}^{2}$, while Ughelli is located in Ughelli North Local Government Area of Delta State with a population of about 441,800 people and land mass of $833 \mathrm{~km}^{2}$ (DSG, 2015). Kwale and Ughelli are the major towns and headquarters of the two Local Government Areas, respectively. Kwale had geographical coordinates of latitude $5.706^{\circ} \mathrm{N}$ and longitude $6.399^{\circ} \mathrm{E}$, while Ughelli had geographical coordinates of latitude $5.501^{\circ} \mathrm{N}$ and longitude $5.973^{\circ} \mathrm{E}$ (Figure 1). Kwale can be classified as an educational and commercial town, as it hosts several oil exploring and production companies, a modular refinery, a 


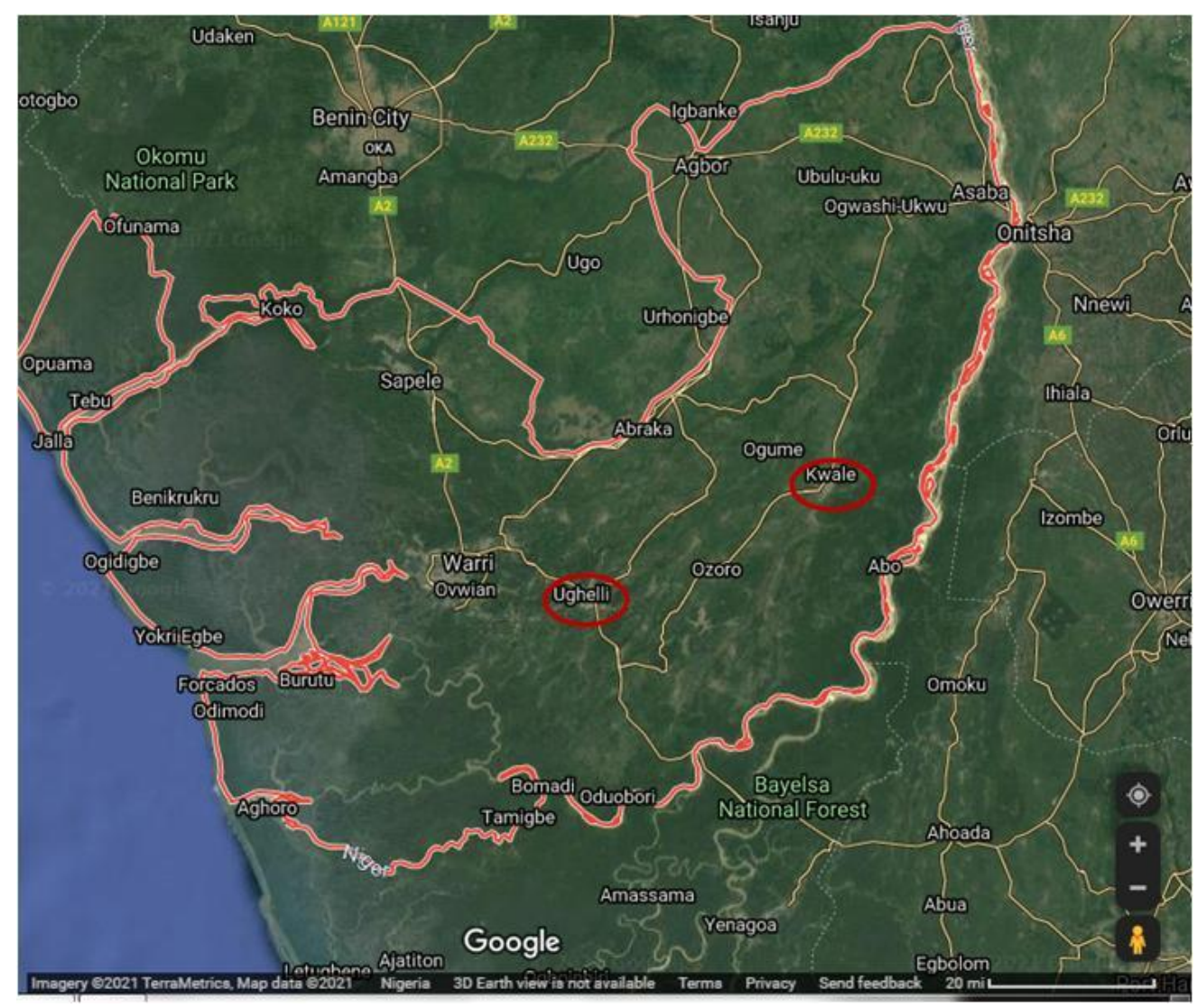

Figure 1. Location of Kwale and Ughelli inside Delta State (Source: Google mapdata, 2020).

university campus, amongst other urban facilities. While Ughelli can be classified as a commercial town, hosting several oil exploring and production companies, a glass production company, and several other production outfits and cottage industries.

Since the year 2010, massive infrastructural developments have taken place within these cities and their environs, some of which include rapid developments in the recreation, hospitality and tourism sector. Therefore, sandcrete block production has become a lucrative business in the two towns. According to sandcrete block factory managers, within a period of 30 days, they sell an average of 50,000 pieces of $225 \mathrm{~mm}$ sandcrete blocks. Also supplies of sandcrete blocks are made to neighboring towns and villages located outside these local government areas.

\section{Materials (sandcrete blocks) acquisition}

Five pieces of $225 \mathrm{~mm}$ and five $150 \mathrm{~mm}$ hollow sandcrete blocks were randomly sampled from 18 major sandcrete blocks producing factories within Ndokwa East LGA and Ughelli North LGA. All the blocks were collected after 28 days of production. The locations of all the sandcrete block production industries sampled were easily accessible by road. To preserve the identity of the factories, the blocks collected from each industry were alphabetically coded. In addition, a well-structured questionnaire was administered to each manager of the individual sandcrete block industries, in other to obtain essential information (nature of fine aggregate used, curing methods, mix ratio and production methods adopted) from them. Answers to these questions aid comprehensive evaluation of the quality of the sandcrete blocks produced. All the sampled blocks collected from the block industries were taken to the Concrete Laboratory of the Department of Civil Engineering Technology, Delta State Polytechnic, Ozoro, Nigeria, for compressive strength test.

\section{Materials used for the sandcrete production}

\section{Cement}

Answers from questionnaires administered to all the blocks industry managers showed that Ordinary Portland Cement (OPC), having different brand names was used as the binder. All the cement brands were in compliance with NIS grade 42.5 , meant for building construction.

\section{Fine aggregate (sand)}

Field observations and answers obtained from the 
questionnaires revealed that, five of the nine sandcrete block producers sampled in Ndokwa East LGA used river bed (sharp) sand, while the remaining four block producers used ordinary dredge (white) sand for their block production. Likewise, the questionnaires revealed that, only three of the nine block producers sampled in Ughelli north LGA used river bed (sharp) sand, while the remaining six block producers used ordinary dredge white sand for their sandcrete block production

\section{Granite fines}

Granite fines were used as partial replacement of fine aggregate, in the production of the customized sandcrete blocks. The granite fines were obtained from Ondo State of Nigeria.

\section{Methods of sandcrete production}

\section{Mix ratio}

Observations made during the field work revealed that volumetric batching method was adopted in all the block industries visited. According to the block industry managers, volumetric batching method is faster and easier than batching by weight, even though it is not as precise as the weight batching method. Apart from the customized blocks producer in Ndokwa East LGA, none of the others block producers adopted any recommended standard for water-cement $(\mathrm{w} / \mathrm{c})$ ratio. They all added water arbitrary to the cement-sand mixture, based mainly on their individual visual perceptions of the appropriate consistency required for the mix.

\section{Mode of block production}

Observations made during the field work showed that most of the block industries used mechanical sandcrete mixers (Figure 2) and vibrating block moulding machines for their block production. A few block factories however engaged the services of manual labourers for the mixing and moulding of their blocks.

\section{Curing}

Field observations revealed that adequate curing of the sandcrete blocks was not done. The block producers mainly just sprinkled water on the blocks surfaces for less than seven consecutive days after production, after which the blocks were arranged in batches (based on their production date). After arrangement, no further curing was carried out on the blocks again, up till when they are eventually sold to the public.

\section{Compressive strength test}

The compressive strength test on all the sandcrete

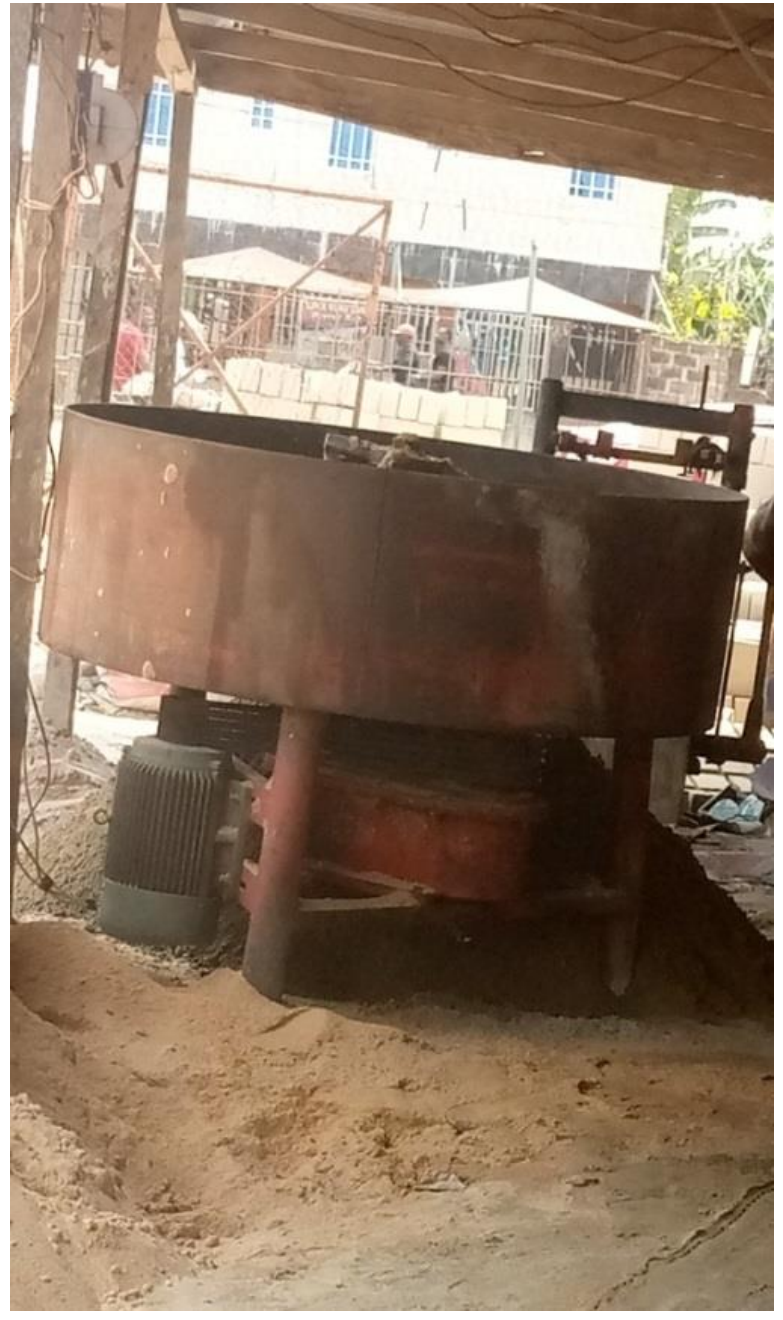

Figure 2. A sandcrete pan mixer.

blocks was carried out in accordance with America Standard Testing Materials (ASTM) International procedures. A digital Concrete Compression Testing Machine (STYE 2000), manufactured in China, was used to test the compressive strength of each individual block. During the testing, an individual block is placed in the machine, and supported by two $12 \mathrm{~mm}$ thick mild steel plates, one on top of the bedding surface and the other at the bottom of the bedding surface (Figure 3 ). Then the block was loaded slowly and axially by upward movement of the bottom platen, until failure was obtained. At failure for each block, the failure load was recorded, and the block removed from the machine. The compressive strength of the sandcrete block was calculated using Equation 1 (Agbi et al., 2020). All the laboratory tests were done under an ambient laboratory temperature of $26 \pm 4^{\circ} \mathrm{C}$.

Compress strength $=\frac{\mathrm{F}}{A}$

Where: $\mathrm{F}=$ crushing force $(\mathrm{N})$ and $\mathrm{A}=$ Net cross sectional area of sandcrete block $\left(\mathrm{mm}^{2}\right)$. 


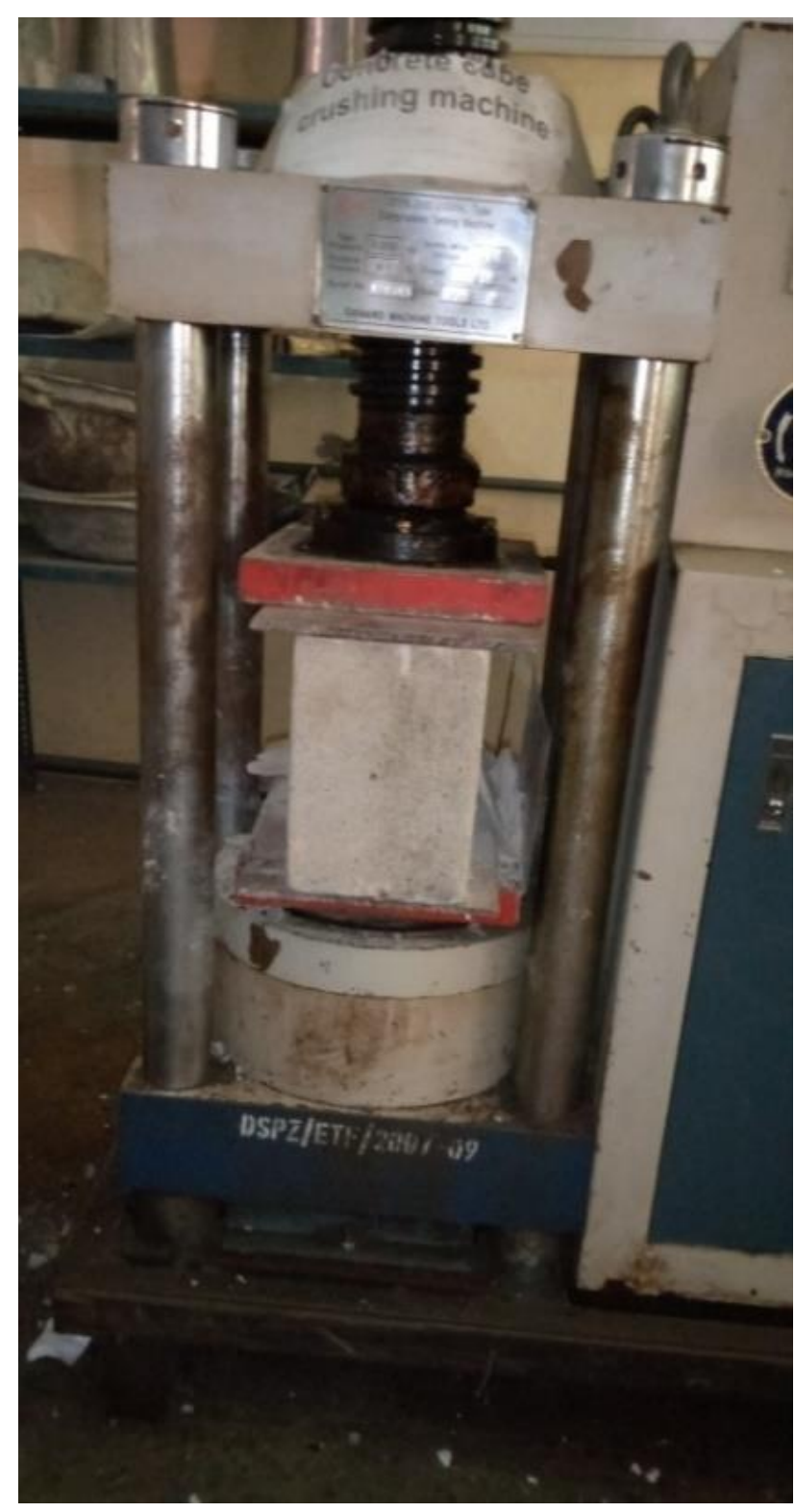

Figure 3. Sandcrete block undergoing compressive testing.

\section{Statistical analysis}

The data obtained were statistically analyzed using the MS Excel 2015 (Microsoft Corporation Redmond, WA 98052). The summary of the readings was plotted in Microsoft Excel 2015.

\section{RESULTS AND DISCUSSION}

\section{Cement- sand mix ratios}

Analysis of results from the questionnaires presented in Table 1 revealed that there was a wide variability in the cement-sand mix ratios adopted by the various block
Table 1. Cement - sand mix ratio.

\begin{tabular}{lc}
\hline Factory & Mix ratio \\
\hline Ndokwa East LGA & \\
Kwa- A & $1: 6$ \\
Kwa- B & $1: 8$ \\
Kwa-C & $1: 12$ \\
Kwa- D & $1: 14$ \\
Kwa-E & $1: 12$ \\
Kwa- F & $1: 10$ \\
Kwa-G & $1: 12$ \\
Kwa- H & $1: 16$ \\
Kwa- I & $1: 18$ \\
& \\
Ughelli North LGA & \\
Ugh - J & $1: 10$ \\
Ugh - K & $1: 8$ \\
Ugh - L & $1: 12$ \\
Ugh - M & $1: 14$ \\
Ugh - N & $1: 16$ \\
Ugh - O & $1: 18$ \\
Ugh - P & $1: 12$ \\
Ugh - Q & $1: 16$ \\
Ugh - R & $1: 14$ \\
\hline
\end{tabular}

producers. Apart from the mix ratio employed for the customize blocks in which the producer adopted the NIS approved cement-sand mix ratio of $1: 6$, all the other block factories failed to meet the NIS approved recommendations for sandcrete blocks. It was observed that 13 of the block factories used very poor cement-sand mix ratios which ranged from 1:12 to $1: 18$ for the production of their sandcrete blocks.

Oral interview with the block industry managers revealed that in order to break even, they generally increased the quantity of sand (being cheaper than cement) in the mass produced sandcrete bocks, thereby adopting a lower cement-sand mix ratio (1:12 and above). This according to the producers is the only way they can recover the money spent on production, with a modest margin of profit, due to the generally low price of sandcrete blocks in the Nigeria. Due to poverty and low level of awareness in Nigeria, very few persons and construction companies buy customized sandcrete blocks for their building works. This is because customized sandcrete blocks are more expensive, compared to mass produced sandcrete blocks. The price of a $225 \mathrm{~mm}$ customized sandcrete blocks cost about 1,000 naira (about 3 US dollars); while the mass produced sandcrete blocks cost 280 naira (about 0. 7 US dollar). This conversion is based on the official monetary conversion rate of 370 naira to 1 US dollar.

\section{Fine aggregate size analysis}

Typical results of the sieve analysis for the fine aggregates 


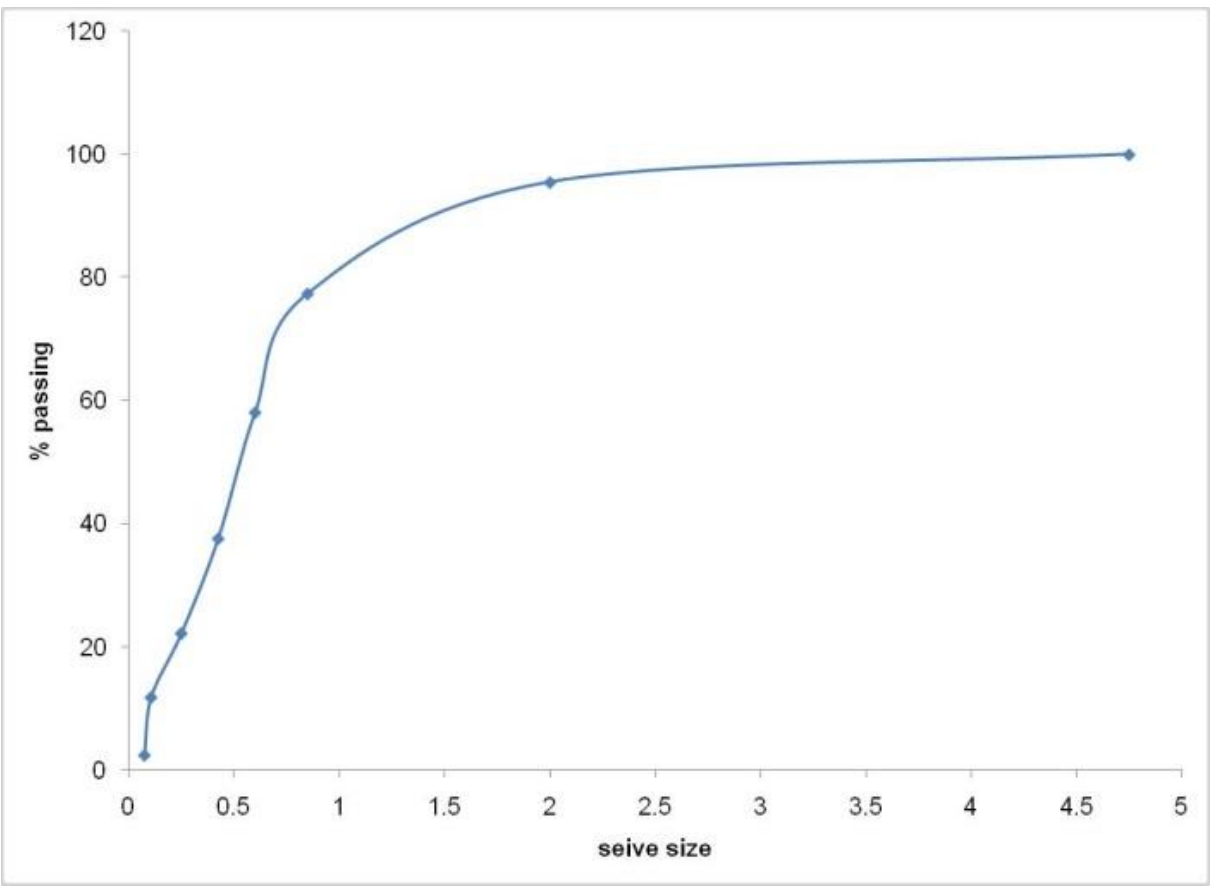

Figure 4. Typical Particle size distribution curve and coefficient of uniformity value for fine aggregate used by Kwa $-\mathrm{A}$ and $\mathrm{Kwa}-\mathrm{C}$ block factories $(\mathrm{Cu}=6.3$; Fines = 2.4).

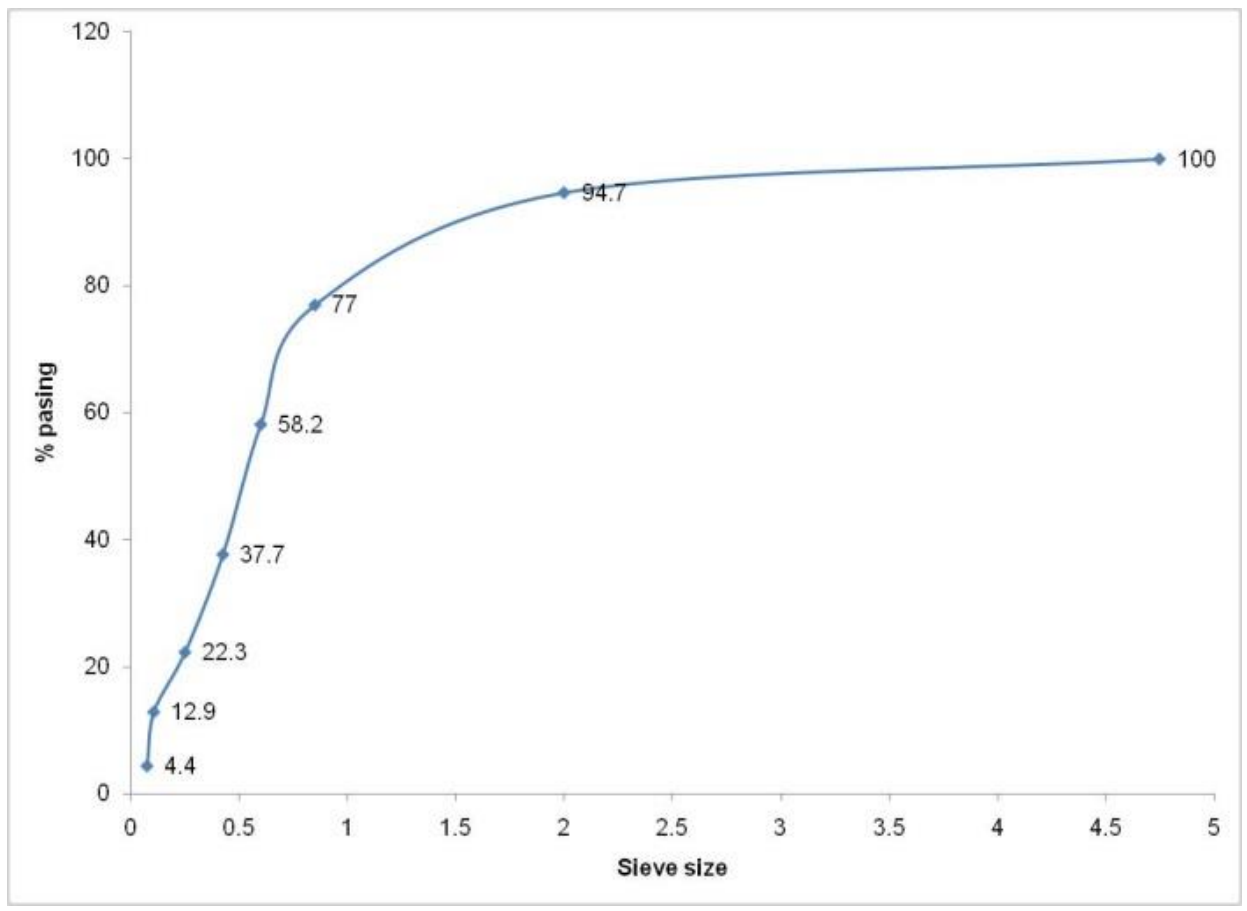

Figure 5. Typical particle size distribution curve and coefficient of uniformity value for fine aggregate used by Kwa - B, Kwa - E, and Kwa - F block factories ( $\mathrm{Cu}=7.5$; Fines = 4.4).

used for the production of the blocks are presented in Figures 4 to 10 . The fine aggregate used by Kwale block producers were collected from three major sources.
Likewise, the sieve analysis results revealed that the Ughelli blocks producers sourced their fine aggregate from four major sources. This is based on the similarities of the 


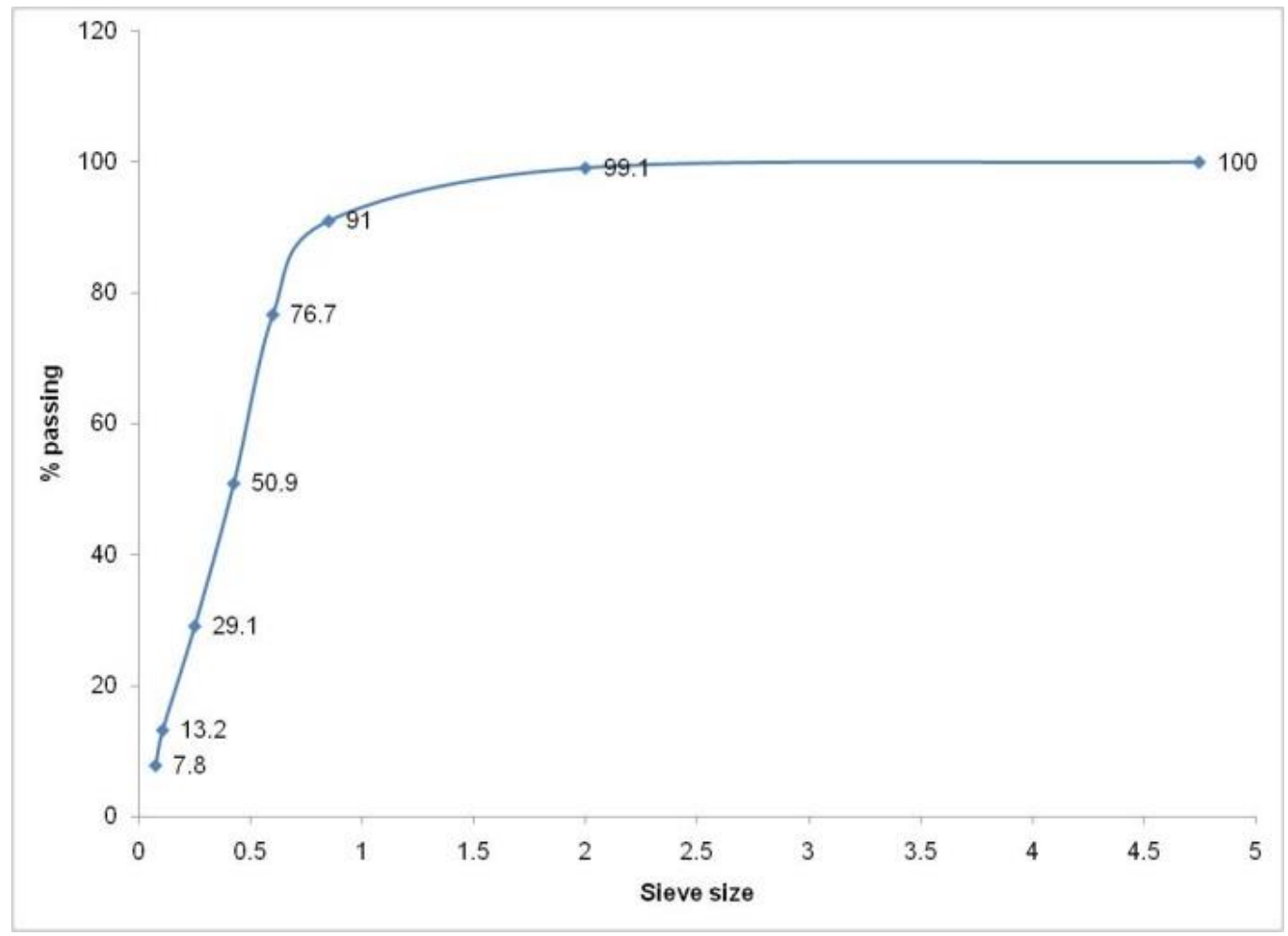

Figure 6. Typical particle size distribution curve and coefficient of uniformity value for fine aggregate used by Kwa-D, Kwa-G, Kwa-H, and Kwa - I block factories ( $\mathrm{Cu}=5.4$; Fines = 7.8).

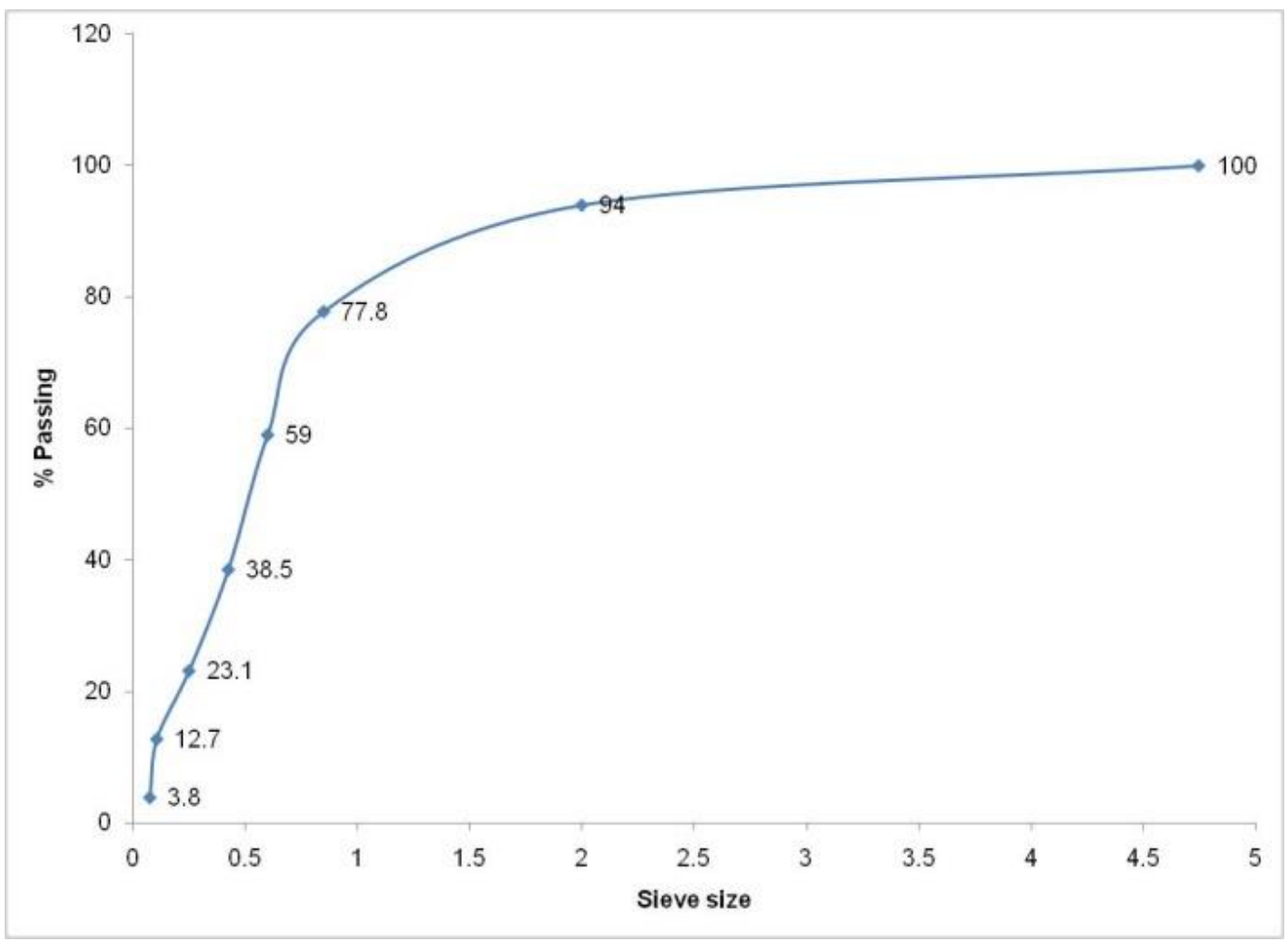

Figure 7. Typical particle size distribution curve and coefficient of uniformity value for fine aggregate used by Ugh - J, Ugh - K, Ugh - L and Ugh - N block factories ( $\mathrm{Cu}=6.3$; Fines = 3.8). 


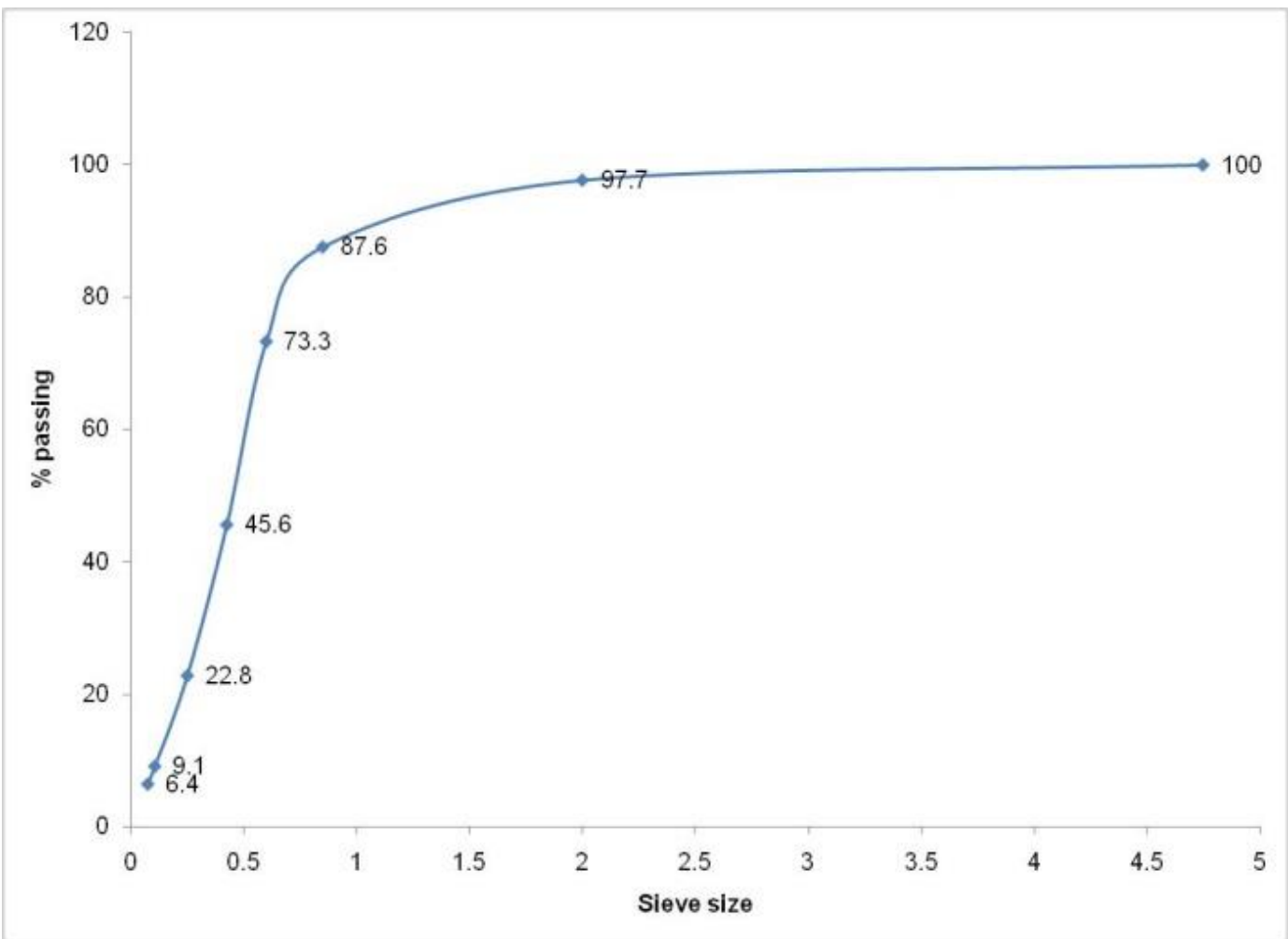

Figure 8. Typical particle size distribution curve and coefficient of uniformity value for fine aggregate used by Ugh $-\mathrm{M}$ and Ugh $-\mathrm{P}$ block factories $(\mathrm{Cu}=5.4$; Fines $=6.4$ ).

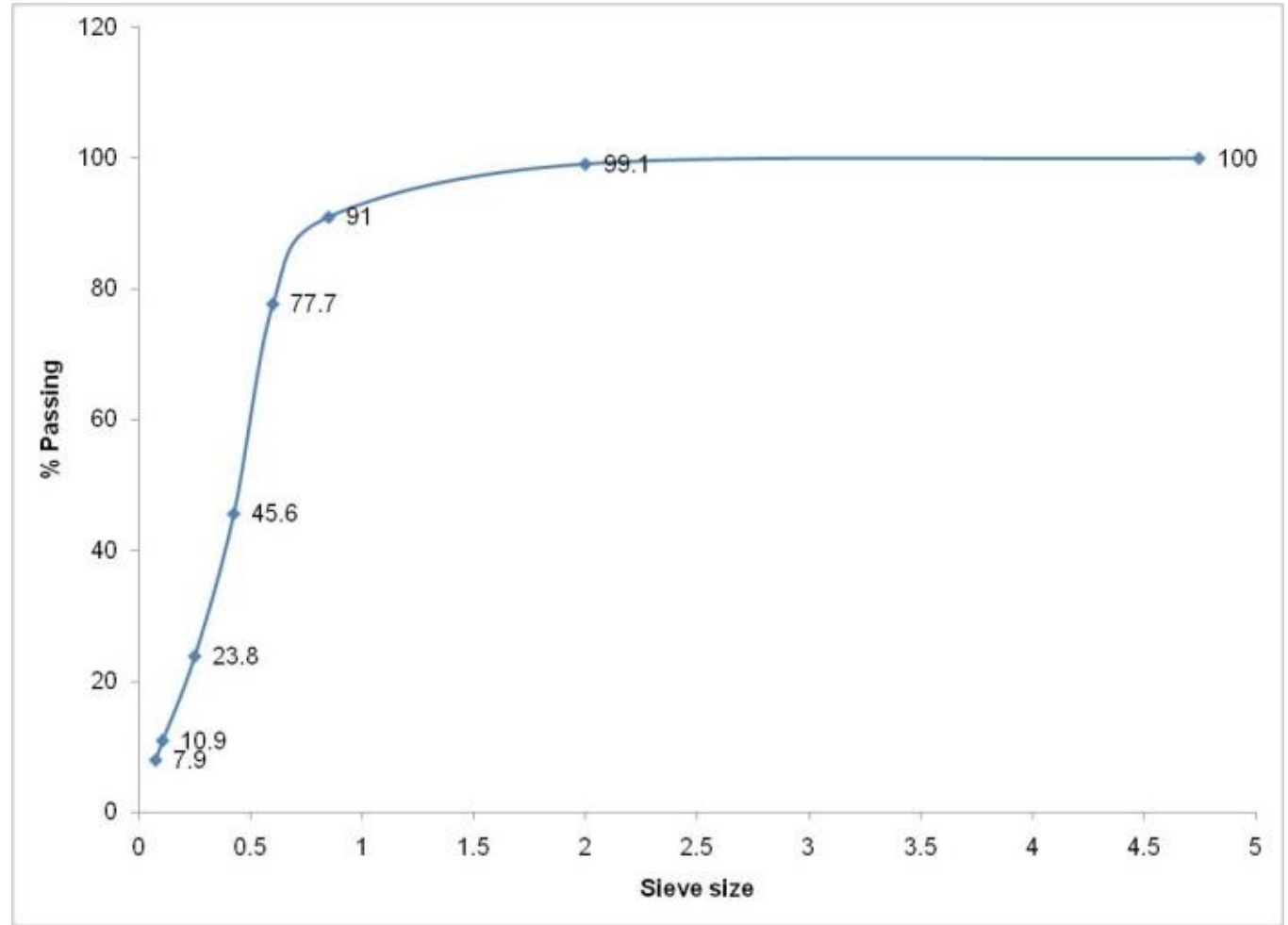

Figure 9. Typical particle size distribution curve and coefficient of uniformity value for fine aggregate used by Ugh $-\mathrm{O}$ and Ugh $-\mathrm{R}$ block factories $(\mathrm{Cu}=5.2$; Fines = 7.9). 


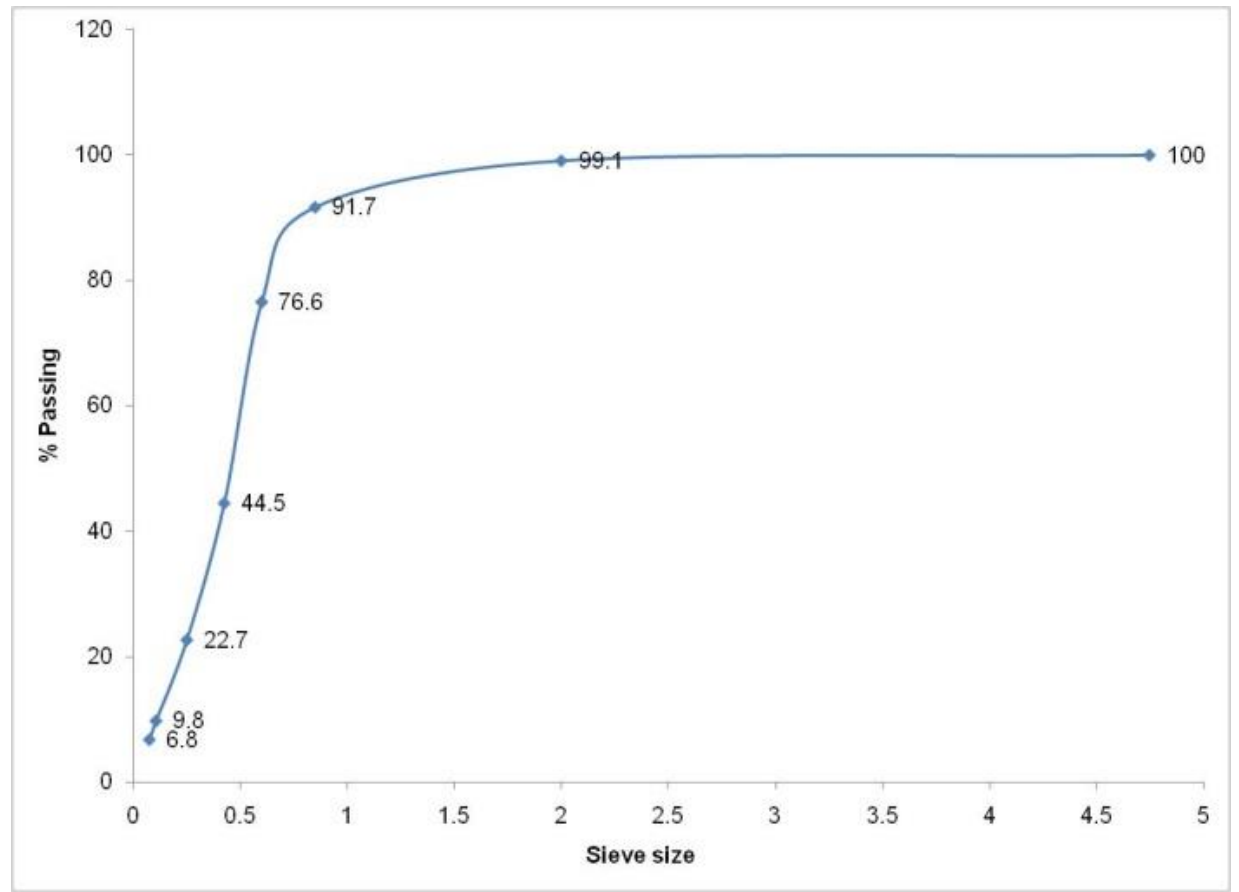

Figure 10. Typical particle size distribution curve and coefficient of uniformity value for fine aggregate used by Ugh $\mathrm{Q}$ block factory $(\mathrm{Cu}=4.9$; Fines $=6.8)$.

properties of the graduation curves. From the analysis of the particle size distribution and the computation of the uniformity coefficient $(\mathrm{Cu})$, it was observed that the fine aggregate used by factories Kwa - A, Kwa - B, Kwa - C, $\mathrm{Kwa}-\mathrm{E}$ and $\mathrm{Kwa}-\mathrm{F}$, for their sandcrete block production, met international (NIS 87 and USCS) requirements; while fine aggregate used by factories Kwa - D, Kwa - G, Kwa $-\mathrm{H}$ and $\mathrm{Kwa}-\mathrm{I}$ for their sandcrete block production, failed to meet international (NIS 87 and USCS) requirements. Similarly, particle size distribution curves and uniformity coefficient results revealed that the fine aggregate used by factories $\mathrm{Ugh}-\mathrm{J}$, Ugh $-\mathrm{K}, \mathrm{Ugh}-\mathrm{L}$ and $\mathrm{Ugh}-\mathrm{N}$ obtained within Ughelli metropolis and employed for their sandcrete block production, met international (NIS 87 and USCS) requirements and are suitable for sandcrete blocks production; while the fine aggregate used by factories Ugh - M, Ugh - O, Ugh - P, Ugh - Q and Ugh - R obtained within Ughelli metropolis and employed for their sandcrete blocks production, failed to meet international (NIS 87 and USCS) requirements and are not suitable for sandcrete block production. According to USCS (2015) fine aggregate (sand) is considered as Poorly Graded (P) when $\mathrm{Cu}<6$ and fines $<5 \%$; and as Well Graded (W) when $\mathrm{Cu} \geq 6$ and fines $<5 \%$.

\section{Compressive Strength of the sandcrete blocks}

The summary of the compressive strength test of the sandcrete blocks sampled from the two major towns in Delta state is presented in Table 2. As seen from the results, the compressive strength of most of the sandcrete blocks produced in the two towns fell below the required minimum compressive strength specified by NIS. According to NIS, sandcrete blocks to be used for the construction of load bearing walls should have minimum compressive strength of 3.45 MPa, while those to be used for the construction of non-load bearing walls should have minimum compressive strength of $2.5 \mathrm{MPa}$ (Agbi et al., 2020). The study revealed that the compressive strength of the sandcrete blocks, regardless of the town of production and mix ratio used, varied widely from one block producer to another. The compressive strength of the $225 \mathrm{~mm}$ sandcrete blocks produced at Ndokwa East LGA ranged from 0.64 to 16.19 $\mathrm{MPa}$, while compressive strength of the $225 \mathrm{~mm}$ sandcrete blocks produced at Ughelli North LGA ranged from 0.61 to 2.85 MPa. Similarly, the compressive strength of $150 \mathrm{~mm}$ sandcrete blocks produced at Ndokwa East LGA ranged from 0.67 to $15.38 \mathrm{MPa}$, while the compressive strength of $150 \mathrm{~mm}$ sandcrete blocks produced at Ughelli North LGA ranged from 0.66 to $2.62 \mathrm{MPa}$. This is in conformity with previous research results by Ewa and Ukpata (2013) and Odeyemi et al. (2018). Ewa and Ukpata (2013) reported that the quality of sandcrete blocks produced in Calabar varied from one manufacturer to the other. They attributed the variation in the compressive strength to the differences in the block production process, and the engineering properties of the constituent materials employed in the sandcrete block production. It was also observed from the results that irrespective of the mix ratios used for the 
Table 2. Compressive strength of the blocks.

\begin{tabular}{llcc}
\hline \multirow{2}{*}{ Location } & Block industry code & \multicolumn{2}{c}{ Compressive strength } \\
\cline { 2 - 4 } & Kwa - A & $\mathbf{9 - \text { inch }}$ & $\mathbf{6 - \text { inch }}$ \\
\hline \multirow{5}{*}{ Kdokwa East } & $16.19 \pm 0.3$ & $15.38 \pm 0.3$ \\
& Kwa - B & $2.8 \pm 0.16$ & $2.60 \pm 0.21$ \\
& Kwa - C & $1.33 \pm 0.1$ & $1.16 \pm 0.04$ \\
& Kwa - D & $1.02 \pm 0.01$ & $1.08 \pm 0.07$ \\
& Kwa - E & $1.13 \pm 0.03$ & $1.21 \pm 0.02$ \\
& Kwa - F & $1.22 \pm 0.06$ & $1.28 \pm 0.03$ \\
& Kwa - G & $0.74 \pm 0.08$ & $0.80 \pm 0.03$ \\
& Kwa - H & $0.77 \pm 0.03$ & $0.81 \pm 0.03$ \\
& Kwa - I & $0.64 \pm 0.06$ & $0.67 \pm 0.05$ \\
& & & \\
& Ugh - J & $1.77 \pm 0.25$ & $1.21 \pm 0.04$ \\
& Ugh - K & $2.85 \pm 0.21$ & $2.62 \pm 0.25$ \\
Ugh - L & $1.79 \pm 0.13$ & $1.97 \pm 0.06$ \\
Ughelli North & $0.74 \pm 0.08$ & $0.66 \pm 0.03$ \\
& Ugh - M & $0.70 \pm 0.03$ & $0.77 \pm 0.05$ \\
& Ugh - N & $0.61 \pm 0.05$ & $0.66 \pm 0.02$ \\
& Ugh - O & $0.68 \pm 0.09$ & $0.67 \pm 0.08$ \\
& Ugh - P & $0.69 \pm 0.03$ & $0.67 \pm 0.02$ \\
& Ugh - Q & & $0.68 \pm 0.10$ \\
\hline
\end{tabular}

production of the sandcrete block, the sandcrete blocks produced within Ndokwa East metropolis were of better quality (compressive strength), compared to the sandcrete blocks produced within Ughelli North metropolis. This could be ascribed to the better fine aggregate quality of the sand used by the block producers at Kwale. The sieve analysis results revealed that river bed sand used by Ndokwa East block factories had better grading quality than the dredge white sand used by the Ughelli North block factories. Additionally, the compressive strength results obtained from this study (0.61 MPa to $16.19 \mathrm{MPa})$ were higher than the ones obtained ( $0.19 \mathrm{MPa}$ and $0.40 \mathrm{MPa})$ by Odeyemi et al. (2018). This could be attributed to the partial replacement of the fine aggregate with granite fines in some of the factories, the production methods and the quality of the fine aggregate employed.

The results also indicated that customized sandcrete blocks (Kwa - A), and the blocks produced with partial replacement of sand with granite fines (Kwa - B, Kwa - C, Ugh - J, Ugh - K and Ugh - L), generally had better compressive strength, regardless of the mix ratio and the production method. Oyekan and Kamiyo (2008) reported that at partial replacement $(15 \%)$ of fine aggregate with granite fines, yielded sandcrete blocks with better compressive strength. The poor quality of the sandcrete blocks produced by factories Kwa - G, Kwa - H, Kwa - I, Ugh $-\mathrm{M}$, Ugh $-\mathrm{N}$, Ugh - O, Ugh - P, Ugh $-\mathrm{Q}$ and Ugh $R$, may be attributed to the poor fine aggregate grade mix ratios used by these block producers. The block factory managers admitted that sandcrete blocks and produced with a larger proportion of cement (higher cement-sand

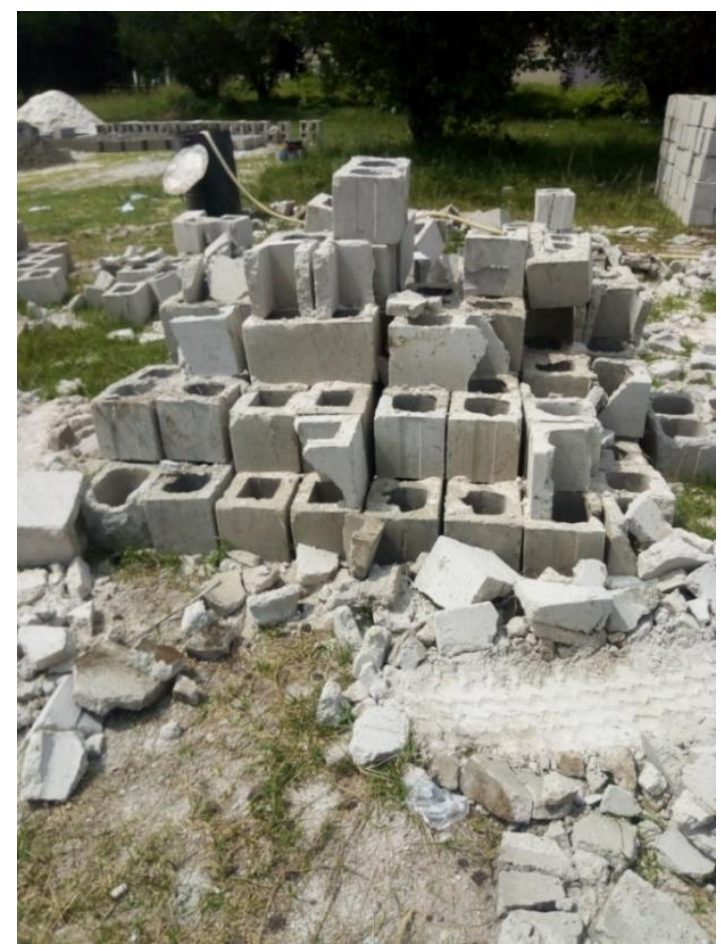

Figure 11. Broken sandcrete blocks littering a construction site in Delta State, Nigeria.

mix ratios of $1: 6$ to $1: 10$ ) tend to have better quality than those produced with lower proportions of cement (cementsand mix ratios greate $r$ than $1: 10)$. The negative implica- 
tion of adopting a very low cement-sand mix ratio $(\geq$ $1: 10)$, in sandcrete block production is that, the low cement volume will lead to poor bonding of the mixture due to low quantity/quality of tobermorite [calcium - silica - hydrate (C-S-H)] gel formation; thereby, leading to weak interfacial adhesion between the sand particles in the sandcrete blocks (Oghenerukewve and Uguru, 2018). Therefore, the resultant sandcrete block will be of a lower quality with a low compressive strength incapable of managing handling stresses, as seen in most of the sandcrete blocks so produced. This has led to the littering of building constructions sites with broken sandcrete blocks as shown in Figure 11.

\section{Conclusion}

This study was carried out to assess the compressive strengths of sandcrete blocks produced in Ndokwa East and Ughelli North Local Government Areas of Delta State, Nigeria. $225 \mathrm{~mm}$ and $150 \mathrm{~mm}$ sandcrete blocks were selected from 18 sandcrete block producing factories within the study area, nine factories from each Local Government Area (LGA). Results obtained from compressive strength tests of the blocks showed that most of the blocks produced in the two LGAs failed to meet NIS requirement for sandcrete blocks. Apart from the customized blocks and those produced by partial replacement of sand with granite fines, the compressive strength of the other sandcrete blocks fell below $1.00 \mathrm{MPa}$, regardless of the block size. The general poor quality of the sandcrete blocks is attributed to poor mix ratios, which fell short of NIS recommendations. This is partly responsible for cracking noticed on block walls within the region. This study revealed that although most massproduced sandcrete blocks in the area fall short of NIS recommendations, standard blocks can be obtained on request through specification by clients. Therefore, customers should specify and insist on superior quality blocks for their buildings and wall construction, despite the higher cost of these high quality sandcrete blocks. Additionally, standard regulatory agencies should closely monitor all the blocks factories and construction sites in the state, to ensure that sandcrete blocks produced within or imported into the state meet NIS recommendations.

\section{CONFLICT OF INTEREST}

The authors declare that they have no conflict of interest.

\section{REFERENCES}

Agbi, G. G., Akpokodje, O. I., \& Uguru, H. (2020). Compressive strength of commercially produced sandcrete blocks within Isoko Metropolis of Delta State. Nigeria Turkish Journal of Agricultural Engineering Research, 1(1), 91-103.

Aiyewalehinmi E. O., \& Tanimola, M. O. (2013). Strength properties of commercially produced sandcrete blocks in Akure: Ondo State. International Journal of Engineering
Science Invention, 2(5), 22-33.

Akeem U, \& Umar G. (2013). Quality assurance of hollow sandcrete blocks produced by block moulding factories in Gombe metropolis. Journal of Science, Technology \& Education, 2(1), 61-65.

Akpokodje, O. I., \& Uguru, H. (2019). Effect of fermented cassava waste water as admixture on some physic-mechanical properties of solid sandcrete blocks. International Journal of Engineering Trends and Technology, 67(10), 216-222.

Ambrose, E. E, Etim, R. K., \& Koffi, N. E. (2019). Quality assessment of commercially produced sandcrete blocks in part of Akwa Ibom State, Nigeria. Nigerian Journal of Technology, 38(3), 586-593.

Anosike, M. N., \& Oyebade, A. A. (2011). Sandcrete block and quality management in Nigeria building industry. Journal of Engineering, Project and Production Management, 2(1), 3746.

Ayedun, C. A., Durodola, O. D., \& Akinjare, O. A. (2010). An empirical ascertainment of the causes of building failure and collapse in Nigeria. Mediterranean Journal of Social Sciences, 3(1), 313-322.

Baiden, B. K., \& Tuuli, M. (2004). Impact of quality control practices in sandcrete blocks production. Journal of Architectural Engineering, 10(2), 55-66.

Delta State Government (DSG) (2015), Delta population. Retrieved on January, 2020 from https://www.deltastate.gov. ng/downloads-2/Population\%20by\%20sex\%20and\%20LGA. pdf.

Google mapdata (2020). Delta State map.

Ewa, D. E., \& Ukpata, J. O. (2013). Investigation of the compressive strengths of commercial sandcrete blocks in Calabar Nigeria. Centre of Professional Research Publications, 3(4), 477-482.

FAO (1988). Farm structures in tropical climates. Lennart P. Bengtsson LP, James H. Whitaker (eds.). Food and Agricultural Organisation.

Mohammed, M., \& Anwar, A. R. (2014). Assessment of structural strength of commercial sandcrete blocks in Kano State. Nigerian Journal of Technological Development, 11(2), 39-43.

Nigerian Industrial Standard (NIS 87) (2000). Standard for sandcrete blocks. Standard Organization of Nigeria. Lagos, 2000.

Odeyemi, S. O., Akinpelu, M. A. Atoyebi, O. D. and Orike, K. J. (2018). Quality Assessment of Sandcrete Blocks Produced in Adeta, Kwara State, Nigeria. Nigerian Journal of Technology, 37(1), 53-59.

Oghenerukewve, P. O., \& Uguru, H. (2018). Effect of fillers loading on the mechanical properties of hardwood sawdust/oil bean shell reinforced epoxy hybrid composites. International Journal of Scientific Research in Science, Engineering and Technology, 4(8), 620-626.

Omoregie, A., \& Alutu, O. E. 2006. The influence of fine aggregate combinations on particle size distribution, grading parameters, and compressive strength of sandcrete blocks. Canadian Journal of Civil Engineering, 33(10), 1271-1278.

Oyekan, G. L., \& Kamiyo, O. M. (2008). Effects of granites fines on the structural and hygrothermal properties of sandcrete blocks. Journal of Engineering and Applied Sciences, 3(9), 735-741.

USCS (2015). Soil classification basics. Retrieved February, 2020 from http://faculty.uml.edu/ehajduk/Teaching/14.330/ documents/14.330SoilClassification.pdf. 